\title{
Model Pembelajaran Kooperatif Tipe Jigsaw II dalam Meningkatkan Kemampuan Matematika Anak
}

\author{
Christiani Endah Poerwati ${ }^{\bowtie}$, Ni Made Ayu Suryaningsih ${ }^{2}$ I Made Elia Cahaya ${ }^{3}$ \\ Pendidikan Guru Pendidikan Anak Usia Dini, Universitas Dhyana Pura, Bali \\ DOI: $10.31004 /$ obsesi.v5i1.496
}

\begin{abstract}
Abstrak
Penelitian ini bertujuan untuk meningkatkan kemampuan matematika anak usia dini. Jenis penelitian ini adalah penelitian tindakan (action research) dengan prosedur empat-tahap, yaitu: 1) Tahap perencanaan, 2) Tahap pengambilan tindakan, 3) Tahap pengembangan, 4) Tahap refleksi. Penelitian dilaksanakan dalam dua siklus. Metode pengumpulan data yang digunakan dalam penelitian ini yakni melalui observasi. Proses pengumpulan data melalui teknik observasi ini menggunakan panduan rubrik untuk merekam data mengenai kemampuan matematika anak selama mengikuti proses pembelajaran. Data yang terkumpul selanjutnya dianalisis secara deskriptif. Hasil penelitian menunjukkan peningkatan kemampuan matematika anak selama penerapan model pembelajaran kooperatif tipe jigsaw II berbantuan benda konkret. Ketuntasan kemampuan matematika anak pada observasi awal 7 anak (29,17\%), siklus I sebanyak 17 anak (70,83\%), dan siklus II 22 anak (91,67\%). Maka dapat dikatakan bahwa model pembelajaran kooperatif tipe jigsaw II berbantuan benda konkret merupakan salah satu alternatif metode pembelajaran yang kreatif, inovatif dan efektif dalam meningkatkan kemampuan matematika anak usia dini.

Kata Kunci: anak usia dini; kemampuan matematika; model pembelajaran kooperatif tipe jigsaw ii
\end{abstract}

\begin{abstract}
This study aims to improve mathematical abilities of early childhood. This type of research is an action research with a four-stage procedure, namely: 1) The planning stage, 2) The stage of taking action, 3) The stage of development, 4) The stage of reflection. The study was conducted in two cycles. Data collection methods used in this study are through observation. The process of collecting data through this observation technique uses a rubric guide to record data about children's mathematical abilities during the learning process. The collected data is then analyzed descriptively. The results showed an increase in children's mathematical abilities during the application of Jigsaw II type cooperative learning models assisted by concrete objects. Completeness of children's mathematical abilities at the initial observation of 7 children $(29.17 \%)$, the first cycle of 17 children $(70.83 \%)$, and the second cycle of 22 children (91.67\%). So it can be said that the Jigsaw II type cooperative learning model assisted by concrete objects is an alternative method of learning that is creative, innovative and effective in improving mathematical abilities of early childhood.
\end{abstract}

Keywords: early childhood; mathematical ability; jigsaw type ii cooperative learning model

Copyright (c) 2020 Christiani Endah Poerwati, Ni Made Ayu Suryaningsih I Made Elia Cahaya

$\triangle$ Corresponding author:

Email Address : diyankonayuki@gmail.com (Banjarmasin, Indonesia)

Received 20 May 2020, Accepted 4 June 2020, Published 7 June 2020 


\section{PENDAHULUAN}

Generasi bangsa yang cerdas, kreatif, inovatif dan berwawasan global merupakan dambaan negara sebagai sumber daya manusia yang berdaya saing tinggi. Pendidikan Anak Usia Dini (PAUD) merupakan lembaga pendidikan pertama bagi pembentukan anak bangsa yang potensial. Setiap anak dilahirkan dengan potensi yang besar, maka menjadi tugas pendidik untuk mengaktualisasikan potensi yang dimiliki anak sehingga tumbuh kembangnya menjadi optimal. Hal ini diamanatkan Permendikbud Nomor 137 Tahun 2014 tentang Standar Nasional Pendidikan Anak Usia Dini, bahwa aspek pengembangan dalam pembelajaran mencakup perkembangan agama dan moral, fisik-motorik, bahasa, kognitif, sosial-emosional, dan seni (Kemendikbud, 2014)

Pengembangan kemampuan kognitif pada anak usia dini menjadi penting untuk diperhatikan dalam pembelajaran di PAUD, karena kemampuan kognitif akan menolong dan menentukan cara anak dalam menyelesaikan masalah yang dihadapi dengan cara yang kreatif dan berbeda. Kemampuan kognitif merupakan salah satu aspek pengembangan dalam pembelajaran di PAUD yang mencakup pengenalan konsep matematika dan sains ( $\mathrm{Li}$ Ling $\mathrm{Hu}, 2016)$. Matematika dan sains seringkali dipandang sebagai pelajaran yang paling sulit pada tingkat pendidikan lanjutan, karena sulit dipahami, bersifat abstrak dan memerlukan daya pikir yang kompleks. Pada dasarnya setiap anak siap mempelajari berbagai konsep termasuk matematika, karena anak memiliki rasa ingin tahu yang besar, senang bertanya dan senang mempelajari hal-hal baru yang ada disekitarnya, maka konsep matematika perlu dikenalkan melalui hubungannya dengan kehidupan sehari-hari yang dekat dengan anak (Camposa, Helena, EurídiceTeixeira, 2015)

Mempelajari matematika di PAUD hendaknya bukan dengan mengajarkan konsep yang rumit mengingat tingkat perkembangan anak prasekolah masih berada pada tingkat pra operasional konkret maka segala sesuatu yang dipelajari akan lebih mudah ditangkap melalui pengalaman langsung dengan benda konkret (Rusiman, Mohd Saifullah, 2017). Selain itu pemilihan strategi dan metode pembelajaran perlu disesuaikan dengan tingkat perkembangan anak, guru hendaknya menggunakan metode yang bervariasi sehingga dapat menciptakan pembelajaran yang menyenangkan dan bermakna.

Model pembelajaran kooperatif merupakan salah satu model pembelajaran yang dapat diterapkan pada anak usia dini, karena model pembelajaran ini memungkinkan anak berperan aktif dalam kelompok, sesuai dengan perkembangan anak yang merupakan usia berkelompok sehingga anak dapat mengembangkan kemampuan sosial emosionalnya. Menurut (Hamdani, 2011) model pembelajaran kooperatif adalah rangkaian belajar anak dalam kelompok tertentu untuk mencapai tujuan pembelajaran yang dirumuskan. Model pembelajaran ini memiliki beberapa tipe diantaranya Student Team Achievement Division (STAD), Tim Ahli (Jigsaw), Investigasi Kelompok (Group Investigation), Think Pair Share (TPS), Numbered Head Together (NHT), dan Team Games Tournament (TGT). Salah satu tipe model pembelajaran kooperatif yang dapat diterapkan pada anak usia dini adalah tipe Jigsaw.

Model pembelajaran kooperatif tipe jigsaw memungkinkan diterapakan pada anak usia dini karena pada tipe ini anak dibagi menjadi beberapa kelompok heterogen, baik dalam kemampuan maupun jenis kelaminnya, sehingga sifat kelompok yang terbentuk menjadi sejajar. Sedangkan kelompok ahli dipilih dari kelompok anak yang memiliki kemampuan matematika yang menonjol, sehingga anak-anak ini akan dapat menjadi tim ahli bagi kelompoknya. Hal ini didukung dengan penelitian yang dilakukan oleh (Sumyadewi, 2014) yang berjudul "Penerapan Model Pembelajaran Cooperative Learning Tipe Jigsaw Berbantuan Media Kartu Angka Bergambar Untuk Meningkatkan Perkembangan Kognitif Anak TK Widhya Brata Mengwi", menunjukkan rata-rata persentase perkembangan kognitif anak kelompok B semester II di TK Widhya Brata Mengwi pada siklus I sebesar $62,19 \%$ berada pada kategori rendah dan rata-rata persentase perkembangan 
kognitif anak kelompok B semester II di TK Widhya Brata Mengwi pada siklus II 87,5\% berada pada kategori tinggi.

Piaget (dalam Papalia, 2008)) membagi 4 tingkat perkembangan kemampuan otak untuk berpikir mengembangkan pengetahuan (Kognitif), yaitu tahapan sensori motorik, pra opreasional kongkrit, operasional kongkrit, dan operasional formal. Anak Taman Kanakkanak berada pada tahapan pra operasional (2-7 tahun). Dikatakan pra operasional karena anak telah menggunakan logika pada tempatnya. Lebih lanjut, tahapan ini dapat dijelaskan sebagai berikut: (1) Pada tahap ini anak mengembangkan kemampuan untuk mengorganisasikan dan mengkoordinasikan serta mempersepsikan dengan gerakan-gerakan dan tindakan-tindakan fisik. Dalam kenyataannya, pra operasional adalah kemampuan anak untuk mengantisipasi pengaruh dari satu kejadian dalam kejadian yang lain; (2) Perkembangan pra operasional anak, memungkinkan anak berpikir dan menyimpulkan eksistensi sebuah benda atau kejadian tertentu walaupun benda atau kejadian itu berada di luar pandangan, pendengaran, atau jangkauan tangannya; (3) Anak mengerti bahwa perubahan dalam satu faktor disebabkan oleh perubahan dalam faktor lain. misalnya dua buah gelas yang berkapasitas sama tetapi berbeda bentuk dituangi air dengan jumlah yang sama maka anak akan cenderung menebak isi gelas yang tinggi lebih banyak daripada isi gelas yang pendek, karena anak hanya mampu melihat pada ketinggian pada gelas air yang tinggi tanpa memperhitungkan kuantitas atau volume yang sama pada gelas yang pendek tetapi besar; (4) Pada tahap ini anak memiliki angan-angan karena ia berpikir secara intuitif yakni berpikir dengan berdasarkan ilham.

Ketika anak-anak pertama datang ke sekolah, mereka membawa rasa ingin tahu, energi, berbagai pengalaman sosial, intelektual dan emosional dan berlimpahnya pengetahuan matematika yang diperoleh dari pengalaman sehari-hari mereka. Hal ini tidak mengherankan karena penelitian telah menunjukkan bahwa kemampuan matematika terbukti ada pada manusia sejak bayi ketika mereka mampu membedakan antara objek yang bervariasi dalam suatu jumlah (Lipton and Spelke, 2003)

Jauh sebelum anak-anak secara formal menggunakan angka, mereka telah menyadarinya melalui pengalaman sehari-hari. Anak-anak menjadi sadar tentang urutan dalam suatu peristiwa sebelum mereka dapat berbicara tentang apa yang pertama, kedua atau ketiga. Ketika mereka mengangkat benda, mereka mengenali ringan atau berat. Berpelukan di pangkuan ibu, anak merasakan diri kecil dan ibunya lebih besar. Anak-anak dapat memberitahu perbedaan dalam ukuran orang, hewan, dan mainan sebelum mereka memiliki gagasan tentang pengukuran. Mereka menyadari, perbedaan antara satu dan banyak dan antara sedikit dan banyak sebelum mereka memperoleh konsep bilangan real. Mereka mengembangkan rasa lama sebelum mereka dapat memberitahu waktu dengan jam. Mereka tahu semua ini dengan realitas pengalaman mereka melalui pengalaman dan melakukan (Mayesky, 2002) Anak-anak membangun pemahaman matematika dengan angka, pola dan aljabar, pengukuran, peluang dan data dan ruang dengan menyelidiki dan berkomunikasi tentang: (1) Jumlah dan representasi mereka, dan atribut dari objek dan himpunan; (2) Posisi, gerakan dan arah; (3) Order, urutan dan pola

Bishop (dalam (Runtukahu, 2014)) mengatakan bahwa dalam setiap kebudayaan bangsa terdapat enam kegiatan matematika secara umum meliputi: Menghitung, Menempatkan (locating), Mengukur, Mendesain, Bermain, dan Menjelaskan (Runtukahu, 2014)

Model pembelajaran kooperatif adalah rangkaian kegiatan belajar yang dilakukan oleh anak dalam kelompok-kelompok tertentu untuk mencapai tujuan pembelajaran yang telah dirumuskan. Slavin (dalam Isjoni, 2014) pembelajaran kooperatif adalah suatu model pembelajaran dimana anak belajar dan bekerja dalam kelompok kelompok kecil secara kolaboratif yang anggotanya 4-6 orang dengan struktur kelompok heterogen. Sedangkan menurut Sunal dan Hans (dalam Isjoni, 2014) mengemukakan bahwa pembelajaran kooperatif merupakan suatu cara pendekatan atau serangkaian strategi yang khusus 
dirancang untuk memberi dorongan kepada anak agar bekerja sama selama proses pembelajaran. Pembelajaran kooperatif tipe jigsaw merupakan salah satu tipe pembelajaran kooperatif yang mendorong anak aktif dan saling membantu dalam penguasaan materi pelajaran untuk mencapai prestasi yang maksimal, (Isjoni, 2014). Pada kegiatan ini keterlibatan guru dalam proses belajar mengajar semakin berkurang dalam arti guru menjadi pusat kegiatan kelas. Guru berperan sebagai fasilitator yang mengarahkan dan memotivasi anak untuk belajar mandiri serta menumbuhkan rasa tanggungjawab.

Menurut (Majid, 2013) model kooperatif Jigsaw II adalah sebuah model belajar kooperatif yang menitikberatkan pada kerja kelompok anak dalam kelompok kecil. Jigsaw tipe II dikembangan oleh Slavin dengan sedikit perbedaan. Dalam belajar kooperatif tipe Jigsaw II, secara umum anak dikelompokkan oleh secara heterogen dalam kemampuan Langkah-langkah pembelajaran dengan Jigsaw II dan juga digunakan oleh peneliti antara lain (Trianto, 2009):

Pendidik menyampaiakan tujuan pembelajaran yang akan diberikan. Memberikan penekanan tentang manfaat penggunaan metode Jigsaw II dalam proses belajar mengajar. Mengingatkan senantiasa percaya diri, kritis dan kooperatif dalam model pembelajaran ini.

Misalkan dalam kelas ada 20 anak, yang diketahui kemampuan matematika-nya dan sudah di-ranking (siswa tidak perlu tahu), anak terbagi atas 25\% (rangking 1-5) kelompok sangat baik, 25\% (ranking 6-10) kelompok baik, 25\% selanjutnya (ranking 11-15) kelompok sedang, 25\%(1520) rendah. Selanjutnya kita akan membaginya menjadi 5 grup (A-E) yang isi tiap-tiap grupnya heterogen dalam kemampuan matematika, berilah indeks 1 untuk anak dalam kelompok sangat baik, indeks 2 untuk kelompok baik, indeks 3 untuk kelompok sedang dan indeks 4 untuk kelompok rendah. Misalkan ( $A 1$ berarti dari grup A kelompok sangat baik, ..., $A 4$ grup A dari kelompok rendah).

Tiap grup akan berisi: Grup A $\{A 1, A 2, A 3, A 4\}$, Grup B $\{B 1, B 2, B 3, B 4\}$, Grup C $\{C 1, C 2, C 3, C 4\}$, Grup D $\{D 1, D 2, D 3, D 4\}$, Grup E $\{E 1, E 2, E 3, E 4\}$

Selanjutnya grup itu dipecah menjadi kelompok yang akan mempelajari materi yang diberikan dan dibina supaya jadi ahli, berdasarkan indeksnya. Kelompok 1 $\{A 1, B 1, C 1, D 1, E 1\}$, Kelompok $2\{A 2, B 2, C 2, D 2, E 2\}$, Kelompok $3\{A 3, B 3, C 3, D 3, E 3\}$, Kelompok 4 $\{A 4, B 4, C 4, D 4, E 4\}$

Tiap kelompok diberi konsep matematika dan sains sesuai dangan kemampuannya. Setiap kelompok diharapkan bisa belajar topik yang diberikan dengan sebaik-baiknya sebelum ia kembali ke dalam grup sebagai tim ahli, tentunya peran pendidik cukup penting dalam fase ini.

Peserta didik ahli dalam konsep tertentu ini, masing-masing kembali dalam grup semula. Pada fase ini kelima grup (1-5) memiliki ahli dalam konsepkonsep tertentu. Selanjutnya pendidik mempersilahkan anggota grup untuk mempresentasikan keahliannya kepada grupnya masing-masing, satu persatu. Proses ini diharapkan dapat terjadi sharing pengetahuan antara mereka. Aturan dalam fase ini adalah: (1) Anak memiliki tanggung jawab untuk memastikan bahwa setiap anggota tim mempelajaari materi yang diberikan; (2) Memperoleh pengetahuan baru adalah tanggung jawab bersama, jadi tidak ada yang selesai belajar sampai setiap anggota menguasai materi yang ada; (3) Tanyakan pada anggota grup sebelum tanya pada pendidik; (4) Pembicaraan dilakukan secara pelan agar tidak mengganggu grup lain; (5) Akhiri diskusi dengan "merayakan" agar memperoleh kepuasan; (6) Tes (Penilaian), pada fase ini guru memberikan tes tulis untuk dikerjakan oleh anak yang memuat seluruh konsep yang didiskusikan. Pada tes ini anak tidak diperkenankan untuk bekerjasama.

Konkret berarti nyata dapat dibuktikan dalam pengertiannya. Seperti yang diungkapkan Rodhatul (Jennah, 2009) bahwa objek adalah “benda sebenarnya yang dapat dijadikan sebagai media pembelajaran" media konkret perlu digunakan untuk mempermudah peserta didik di dalam proses pembelajaran untuk mencapai tujuan pengajaran. Sedangkan menurut (Ibrahim, R., 2003), yang dimaksud media konkret yaitu “ 
untuk mencapai hasil yang optimal dari proses belajar mengajar salah satu yang disarankan dalam digunakannya pula media yang bersifat langsung, bersifat nyata atau realita".

Menurut Perdana (2007) dalam media konkret mempunyai lima manfaat yaitu: (1) Memperjelas pesan agar tidak terlalu verbal; (2) Mengatasi keterbatasan ruang, waktu, tenaga, dan daya indera; (3) Menimbulkan gairah belajar, interaksi lebih langsung antara peserta didik dengan guru; (4) Memungkinkan peserta didik belajar mandiri sesuai dengan bakat dan kemampuannya; dan (5) Memberi rangsangan yang sama, mempersamakan pengalaman dan menimbulkan prestasi yang sama.

Berdasarkan pendapat di atas dapat disimpulkan bahwa media konkret dapat memperjelas pesan yang disampaikan kepada peserta didik, media konkret dapat memberikan rangsangan belajar dan proses belajar mengajar pun menjadi menarik perhatian peserta didik.

Penggunaan media didalam proses belajar mengajar bukan bermaksud mengganti cara mengajar yang baik, melainkan untuk melengkapi dan membantu pendidik dalam penyampaian materi atau informasi pelajaran, dengan menggunakan media diharapkan terjadi interaksi antara pendidik dengan peserta didik secara maksimal dapat mencapai hasil belajar yang sesuai dengan tujuan. Secara umum tujuan dari penggunaan pesan-pesan atau materi pembelajaran kepada peserta didik agar pesan lebih mudah dimengerti, lebih menarik, dan lebih menyenangkan kepada peserta didik dan dengan digunakannya media konkret ini pada proses pembelajaran maka akan memudahkan peserta didik untuk mempelajari sesuatu atau pun dalam situasi yang nyata.

\section{METODOLOGI}

Penelitian ini menggunakan desain penelitian tindakan (action research) yang secara umum bertujuan untuk meningkatkan kemampuan matematika anak usia dini. Penelitian ini dirancang dalam dua siklus. Setiap siklus terdiri dari empat tahapan yaitu perencanaan tindakan, pelaksanaan tindakan, observsi/evaluasi, dan refleksi. Penelitian ini dilakukan untuk melihat efektifitas model pembelajaran kooperatif tipe jigsaw II berbantuan benda konkret dalam meningkatkan kemampuan matematika anak usia dini,

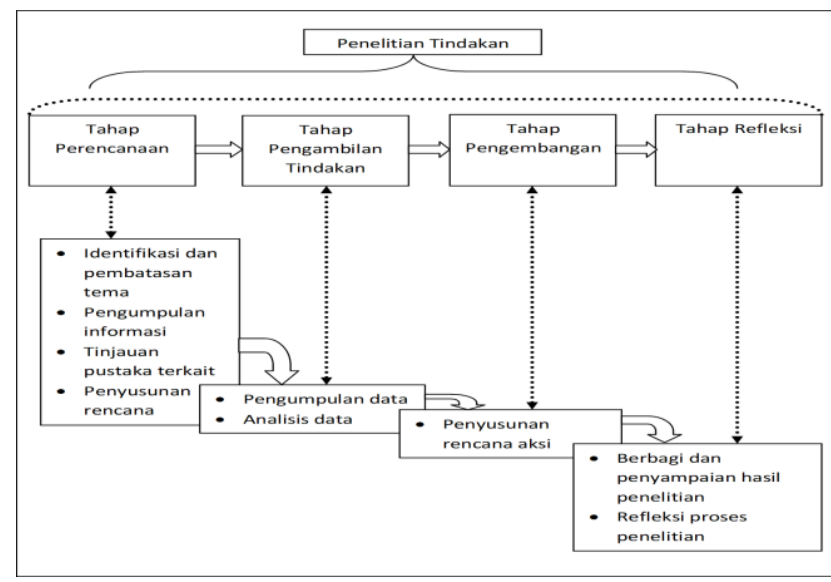

Bagan 1. Empat-Tahap Penelitian Tindakan (Sumber : Mertler, 2011)

Metode pengumpulan data yang digunakan dalam penelitian ini yakni melalui observasi. Proses pengumpulan data melalui teknik observasi ini menggunakan panduan rubrik untuk merekam data mengenai kemampuan matematika yang ditunjukan anak selama pembelajaran dengan model pembelajaran kooperatif tipe jigsaw II berbantuan benda konkret. Menurut Mills, (dalam (Kunandar, 2010)), Pengamatan dapat dilaksanakan dengan pedoman pengamatan (format, daftar cek), catatan lapangan, jurnal harian, aktivitas 
dikelas, penggambaran interaksi dalam, alat perekam elektronik atau pemetaan kelas. Proses pencatatan dapat dibantu dengan menggunakan instrumen.

Data peningkatan kemampuan matematika anak dianalisis secara deskriptif, yaitu dengan malakukan observasi terhadap aktifitas yang dilakukan anak dengan bantuan instrument penilaian. Keberhasilan anak dalam peningkatan kemampuan matematika dikatagorikan menjadi lima katagori yaitu sangat tinggi, tinggi, sedang, rendah dan sangat rendah. Cara menghitungnya adalah dengan mencari rata-rata, minimal memenuhi katagori baik. Tingkat kreativitas anak dapat ditentukan dengan membandingkan persentase penguasaan ke dalam konversi Penilaian Acuan Patokan (PAP) skala lima.

Tabel 1. Pedoman Konversi Penilaian Acuan Patokan (PAP) Nasional

\begin{tabular}{ccc}
\hline Persentase Penguasaan & Katagori & Ketuntasan \\
\hline $90-100$ & Sangat tinggi & Tuntas \\
$80-89$ & Tinggi & Tuntas \\
$65-79$ & Sedang & Tuntas \\
$55-64$ & Rendah & Belum Tuntas \\
$00-54$ & Sangat rendah & Belum Tuntas \\
\hline \multicolumn{3}{c}{ Sumber : (Agung, 2014) }
\end{tabular}

Kriteria keberhasilan dalam penelitian ini adalah jika terjadi peningkatan kemampuan matematika anak melalui model pembelajaran kooperatif tipe jigsaw II. Indikator keberhasilan dalam penelitian ini apabila minimal $80 \%$ dari jumlah anak didik memenuhi kriteria sedang.

\section{HASIL DAN PEMBAHASAN}

Orientasi awal melalui observasi awal. Observasi awal dilaksanakan untuk mengetahui tingkat kemampuan matematika anak usia dini pada saat mengikuti proses pembelajaran sebelum dilakukannya tindakan. Hasil observasi awal menunjukkan kemampuan matematika anak masih rendah. Persentase ketuntasan dicapai oleh 7 anak $(29,17 \%)$, dengan katagori sedang hingga tinggi, 17 anak (70,83\%) masih berada dikategori rendah dan sangat rendah. Maka perlu dilakukan suatu tindak lanjut sebagai upaya perbaikan kemampuan matematika anak melalui tindakan kelas dengan model pembelajaran kooperatif tipe jigsaw II berbantuan benda konkret sesuai prosedur yang telah ditetapkan dan disiapkan.

\section{Siklus I}

Hal-hal yang dipersiapkan dalam siklus I ini meliputi Rencana Kegiatan Mingguan (RKM), Rencana Kegaiatan Harian (RKH), skenario pembelajaran, media pembelajaran berupa benda konkret, instrumen pemantauan kemampuan matematika dan rubrik penilaian kemampuan sosial emosional. Rencana Kegiatan Mingguan (RKM), Rencana Kegaiatan Harian (RKH), dan skenario pembelajaran dirancang dan disusun sesuai dengan tema yang digunakan di PAUD Tunas Mekar II Dalung. Siklus I direncanakan dengan 2 kegiatan pembelajaran dengan model pembelajaran kooperatif tipe jigsaw II, masing-masing kegiatan dilaksanakan berdasarkan skenario pembelajaran. Proses penelitian menggunakan metode observasi pada setiap pertemuannya untuk menilai tingkat kemampuan matematika anak.

Siklus I dilaksanakan sesuai dengan skenario pembelajaran yang telah disiapkan.Upaya yang diberikan untuk meningkatkan kemampuan matematika pada anak usia dini yakni melalui penerapan model pembelajaran kooperatif tipe Jigsawa II dalam proses pembelajaran. Peningkatan kemampuan berbahasa anak dilakukan melalui penerapan model pembelajaran kooperatif tipe Jigsaw II. Secara rinci nilai rata-rata kemampuan matematika anak pada siklus I. Secara rinci hasil observasi terhadap 
kemampuan matematika saat menggunakan penerapan model pembelajaran kooperatif tipe Jigsaw II pada siklus I dapat diperhatikan dalam Tabel 2 berikut ini.

Tabel 2. Data Kemampuan Matematika Anak Siklus I

\begin{tabular}{|c|c|c|c|c|c|c|c|c|c|c|c|c|c|}
\hline & & & & ilikate & ampu & tems & & & & & & & \\
\hline No & Subyek & $\frac{A}{3}$ & $\mathrm{~B}$ & C & $\mathrm{D}$ & E & $\mathrm{F}$ & G & $J \mathrm{Imh}$ & Rata-rata & Persentase & Kategori & $\begin{array}{c}\text { Ketuntasan } \\
\text { Tutass }\end{array}$ \\
\hline$\frac{1}{2}$ & $\frac{\mathrm{A}}{\mathrm{B}}$ & $\frac{3}{3}$ & $\frac{3}{3}$ & $\frac{3}{3}$ & $\frac{3}{3}$ & $\frac{3}{4}$ & $\frac{4}{3}$ & $\frac{4}{4}$ & $\frac{23}{23}$ & $\begin{array}{l}3,29 \\
3,29 \\
\end{array}$ & $\begin{array}{l}65,71 \\
65,71 \\
\end{array}$ & $\begin{array}{l}\text { Sedang } \\
\text { Sedang }\end{array}$ & $\begin{array}{l}\text { Tuntas } \\
\text { Tuntas }\end{array}$ \\
\hline 3 & C & 3 & 3 & 4 & 3 & 2 & 3 & 4 & 22 & 3,14 & 62,86 & Rendah & Belum Tuntas \\
\hline 4 & D & 4 & 4 & 4 & 4 & 4 & 4 & 4 & 28 & 4,00 & 80,00 & Tinggi & \begin{tabular}{|l|} 
Tuntas \\
\end{tabular} \\
\hline 5 & $\mathrm{E}$ & 3 & 3 & 3 & 3 & 4 & 4 & 4 & 24 & 3,43 & 68,57 & Sedang & Tuntas \\
\hline & $\mathrm{F}$ & 3 & 3 & 3 & 3 & 3 & 4 & 4 & 23 & 3,29 & 65,71 & Sedang & Tuntas \\
\hline 7 & G & 3 & 2 & 3 & 3 & 2 & 4 & 4 & 21 & 3,00 & 60,00 & Rendah & Belum Tuntas \\
\hline 8 & $\mathrm{H}$ & $\frac{3}{3}$ & $\frac{3}{3}$ & 3 & $\frac{3}{3}$ & $\frac{2}{3}$ & $\frac{3}{3}$ & 3 & 20 & 2,86 & 57,14 & Rendah & Belum Tuntas \\
\hline$\frac{9}{10}$ & $\mathrm{I}$ & 3 & $\frac{3}{3}$ & 3 & $\frac{3}{3}$ & 3 & 3 & 3 & 21 & & 60,00 & Rendah & Belum Tuntas \\
\hline$\frac{10}{11}$ & $\frac{\mathrm{J}}{\mathrm{K}}$ & $\frac{3}{3}$ & $\frac{3}{3}$ & $\frac{3}{3}$ & $\frac{3}{3}$ & $\frac{3}{3}$ & $\frac{4}{4}$ & $\frac{4}{4}$ & $\frac{23}{23}$ & 3,29 & 65,71 & $\begin{array}{l}\text { Sedang } \\
\text { Sedana }\end{array}$ & $\begin{array}{l}\text { Tuntas } \\
\text { Tuntas }\end{array}$ \\
\hline 12 & $\mathrm{~K}$ & $\frac{3}{4}$ & $\frac{3}{3}$ & $\frac{3}{3}$ & $\frac{3}{3}$ & $\frac{3}{5}$ & $\frac{4}{5}$ & $\frac{4}{5}$ & $\frac{23}{28}$ & $\frac{3,29}{4,00}$ & $\frac{65,71}{80,00}$ & 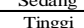 & $\frac{\text { Tuntas }}{\text { Tuntas }}$ \\
\hline 13 & M & 4 & 4 & 4 & 4 & 5 & 5 & 5 & 31 & 4,43 & 88,57 & $\begin{array}{l}\text { Tingggi } \\
\text { Tingi }\end{array}$ & $\begin{array}{l}\text { luntas } \\
\text { Tuntas }\end{array}$ \\
\hline 14 & $\mathrm{~N}$ & 2 & 3 & 3 & 3 & 4 & $\overline{4}$ & 4 & 23 & 3,29 & 65,71 & Sedang & Tuntas \\
\hline 15 & $\mathrm{O}$ & 3 & 3 & 3 & 3 & 4 & $\overline{4}$ & 4 & 24 & 3,43 & 68,57 & Sedang & Tuntas \\
\hline 16 & $\mathrm{P}$ & 3 & 3 & 3 & 3 & 3 & 3 & 3 & 21 & 3,00 & 60,00 & Rendah & Belum Tuntas \\
\hline 17 & $\mathrm{Q}$ & 3 & 3 & 3 & 3 & 4 & 4 & 4 & 24 & 3,43 & 68,5 & Sedang & Tuntas \\
\hline 18 & $\mathrm{R}$ & 3 & 3 & 3 & 3 & 3 & 4 & 4 & 23 & 3,29 & 65,71 & Sedang & Tuntas \\
\hline$\frac{19}{20}$ & $\frac{S}{T}$ & $\frac{4}{3}$ & 4 & 4 & 4 & $\frac{4}{5}$ & $\frac{4}{5}$ & $\frac{5}{5}$ & 29 & 4,14 & 82,86 & & Tuntas \\
\hline 20 & $\frac{T}{U}$ & $\frac{3}{3}$ & $\frac{3}{3}$ & $\frac{4}{3}$ & 4 & 5 & $\frac{5}{3}$ & $\frac{5}{3}$ & 29 & 4,14 & 82,86 & Tinggi & Tuntas \\
\hline$\frac{21}{22}$ & $\mathrm{v}$ & $\frac{3}{3}$ & 3 & $\frac{3}{3}$ & $\frac{2}{3}$ & $\frac{4}{3}$ & $\frac{3}{3}$ & $\frac{3}{3}$ & $\frac{21}{21}$ & 3,00 & 60,00 & Rendah & Belum Tuntas \\
\hline 23 & w & 4 & 3 & 4 & 3 & 4 & 4 & 4 & 26 & 3,71 & 74,29 & $\begin{array}{l}\text { Rendah } \\
\text { Sedang }\end{array}$ & $\begin{array}{l}\text { Belum Tuntas } \\
\text { Tuntas }\end{array}$ \\
\hline 24 & $x$ & 4 & 4 & 4 & 4 & 4 & 3 & 4 & 27 & 3,86 & 77,14 & Sedang & Tuntas \\
\hline & & & & & & & & & & & 57,14 & & \\
\hline $\max$ & & & & & & & & & & & 88,57 & & \\
\hline ian & & & & & & & & & & & $\frac{68,81}{65,71}$ & & \\
\hline nodus & & & & & & & & & & & 65,71429 & & \\
\hline tandar. & & & & & & & & & & & 8,752403 & & \\
\hline
\end{tabular}

Tabel di atas, menunjukkan adanya peningkatan kemampuan matematika anak usia dini. Pada saat observasi awal, 7 anak $(29,17 \%)$ yang mencapai ketuntasan. Setelah penerapan model pembelajaran kooperatif tipe jigsaw II berbantuan benda konkret terjadi peningkatan ketuntasan menjadi 17 anak $(70,83 \%)$ dengan rincian anak pada kategori sedang sebanyak 12 anak, 5 anak pada kategoti tinggi.. Sedangkan 7 anak belum tuntas $(29,17 \%)$ masih pada kategori rendah.

Hasil pemantauan seperti yang dipaparkan di atas menunjukkan bahwa secara umum kemampuan matematika anak PAUD Tunas Mekar II Dalung mengalami peningkatan. Pada diagram berikut ditunjukkan Persentase penguasaan kemampuan matematika pada observasi awal dan siklus 1.

Berdasarkan hasil observasi pada siklus I diadakan refleksi dengan diskusi antara peneliti, guru dan kepala sekolah maka diidentifikasi kendala dan perbaikan yang memungkinkan dilakukan. Pelaksanaan siklus I dijumpai beberapa kendala diantaranya : masih dijumpai anak pada kelompok ahli belum mampu memimpin kelompoknya untuk berdiskusi dan mengerjakan permainan matematika, beberapa anak mengalami kesulitan dalam memahami instruksi dalam mengerjakan lembar kerja matematika, banyak anak mengalami kesulitan mengerjakan lembar kerja karena cenderung meniru jawaban temannya tanpa memahami instruksi sehingga menyelesaikan lembar kerja kurang maksimal, sebagian anak memahami saat mengerjakan permainan matematika, namun mengalami kebingungan saat mengerjakan mengerjakan lembar kerja, dan kesenjangan kemampuan anak, dimana ada beberapa anak sangat lancar dalam mengenal lambang bilangan, kemampuan menulis dan memahami gambar, namun beberapa anak memiliki kemampuan yang masih rendah.

Sedangkan faktor pendukung dalam penerapan model pembelajaran kooperatif tipe Jigsaw II adalah sebagai berikut: kegiatan permainan matematika dengan benda konkret menarik perhatian, antusias, dan partisipasi anak untuk melakukan kegiatan, antusias dan kemampuan komunikasi tim ahli dalam memimpin dan mentransfer pengetahuan pada teman kelompoknya, rasa ingin tahu yang besar pada anak, dan partisipasi dan kerjasama peneliti, tim guru dan kepala sekolah

Berdasarkan kendala-kendala yang ditemui dan perlunya mengoptimalkan faktorfaktor pendukung pelaksanaan siklus I maka siklus II perlu dilaksanakan dengan pertimbangan persentase ketuntasan kemampuan matematika anak belum mencapai $80 \%$ 
dan perlunya beberapa perbaikan kegiatan sehingga kendala yang ada di siklus I dapat teratasi dengan baik dan kemampuan matematika anak pada siklus II dapat meningkat.

Perbaikan yang dapat dilakukan pada siklus II adalah memberi motivasi dan apresiasi yang memadai kepada anak sehingga dapat menumbuhkan minat anak untuk berpartisipasi aktif dan bekerja sama dalam menghasilkan karya hasil proyek sebagai karya bersama. Hal ini sejalan dengan pernyataan (Kartono, 2007), bahwa anak merupakan pribadi sosial yang memerlukan relasi dan komunikasi dengan orang lain untuk memanusiakan dirinya. Anak ingin dicintai, ingin diakui dan dihargai.

\section{Siklus II}

Tahap perencanaan dan persiapan dalam siklus II seperti halnya siklus I meliputi Rencana Kegiatan Mingguan (RKM), Rencana Kegaiatan Harian (RKH), skenario pembelajaran, media pembelajaran, instrumen pemantauan kemampuan matematika dan rubrik penilaian kemampuan matematika. Rencana Kegiatan Mingguan (RKM), Rencana Kegaiatan Harian (RKH), dan skenario pembelajaran dirancang dan disusun sesuai dengan tema yang digunakan di TK Tunas Mekar II Dalung. Siklus II direncanakan untuk 2 kali kegiatan permainan matematika, masing-masing kegiatan dilaksanakan berdasarkan skenario pembelajaran. Proses penelitian menggunakan metode observasi pada setiap pertemuannya untuk menilai tingkat kemampuan matematika anak.

Pelaksanaan tindakan siklus II sesuai dengan skenario pembelajaran yang telah disiapkan. Menggunakan permainan matematika dengan penerapan model pembelajaran kooperatif tipe jigsaw II.

Berdasarkan hasil observasi pada siklus I, secara umum terjadi peningkatan kemampuan matematika anak usia dini, namun masih ada anak yang memperoleh katagori rendah. Maka untuk meningkatkan kemampuan matematika anak usia dini, penerapan model pembelajaran kooperatif tipe Jigsaw II kembali dilanjutkan pada siklus II.

Hasil observasi terhadap kemampuan matematika anak usia dini pada siklus II dapat diperhatikan dalam Tabel 3 berikut ini.

Tabel 3. Data Kemampuan Matematika Anak Siklus II

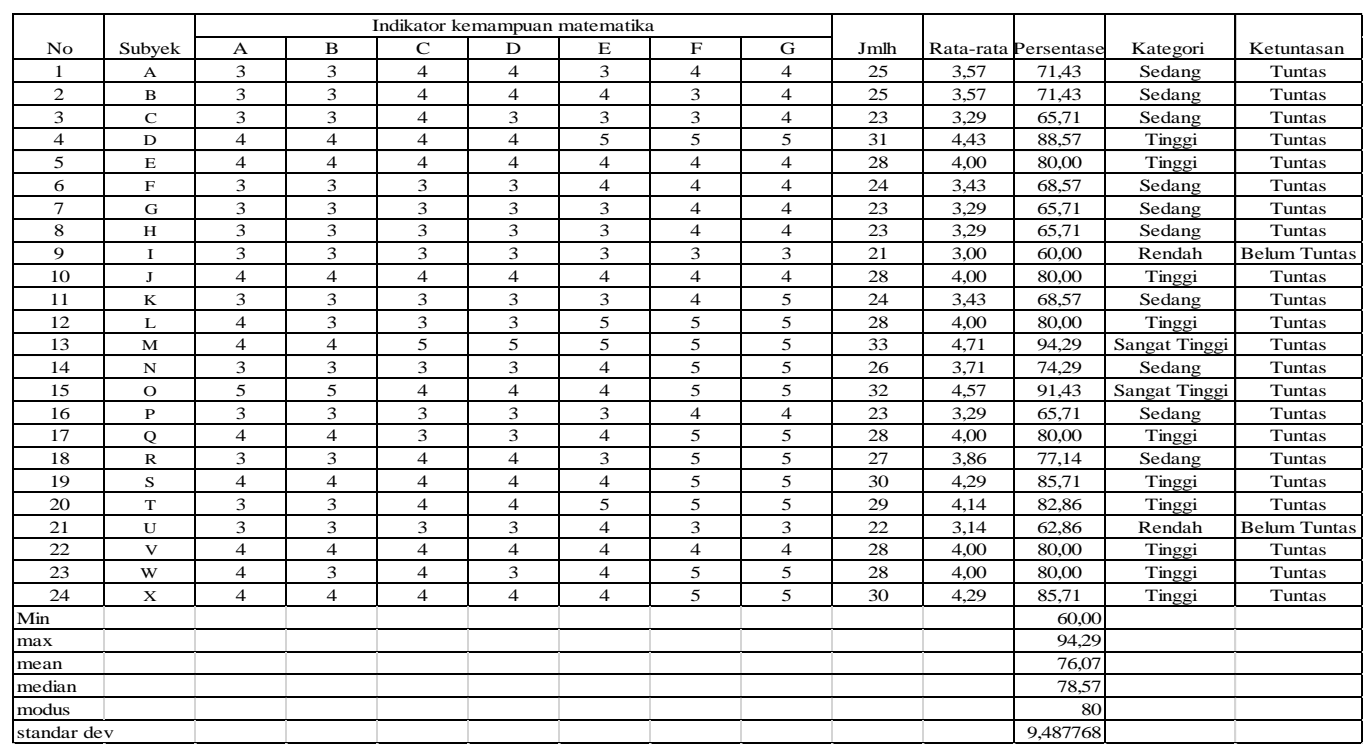

Pada tabel 3 dapat dilihat tingkat ketuntasan kemampuan matematika setiap anak pada Siklus II, terlihat adanya peningkatan setelah mengikuti proses pembelajaran dengan model pembelajaran kooperatif tipe Jigsaw II. Hal ini ditunjukkan dari meningkatnya jumlah ketuntasan kemampuan matematika anak usia dini, yakni 22 anak (91,67\%). Ada 2 orang anak $(8,33 \%)$ masih belum mencapai tingkat ketuntasan yang ditentukan. 
Hasil pemantauan dari kegiatan siklus II kemampuan matematika anak mengalami peningkatan yang signifikan. Ketuntasan kemampuan matematika anak telah mencapai 91,67\% (meningkat 20,84\%) dari siklus I yaitu sebanyak 22 anak telah mencapai ketuntasan dengan kategori sedang (10 anak), tinggi (10 anak), dan sangat tinggi (2 anak) hanya menyisakan 2 anak dengan kategori rendah sehingga persentase penguasaan kemampuan matematika yang belum tuntas $(8,33 \%)$. Bila dibandingkan dengan siklus I terdapat 4 anak dengan kategori rendah meningkat menjadi kategori sedang, 5 anak dengan kategori sedang menjadi tinggi, 1 anak dengan kategori tinggi meningkat menjadi kategori sangat tinggi, 1 anak dengan kategori sedang meningkat menjadi kategori sangat tinggi, 1 anak dengan kategori rendah menjadi tinggi, 4 anak dengan kategori tinggi dan 6 anak pada kategori sedang berada pada kategori yang sama. Berdasarkan kategori tingkat kemampuan matematika anak dapat dilihat perbandingannya dari observasi awal, siklus I dan siklus II, sebagaimana pada gambar berikut ini.

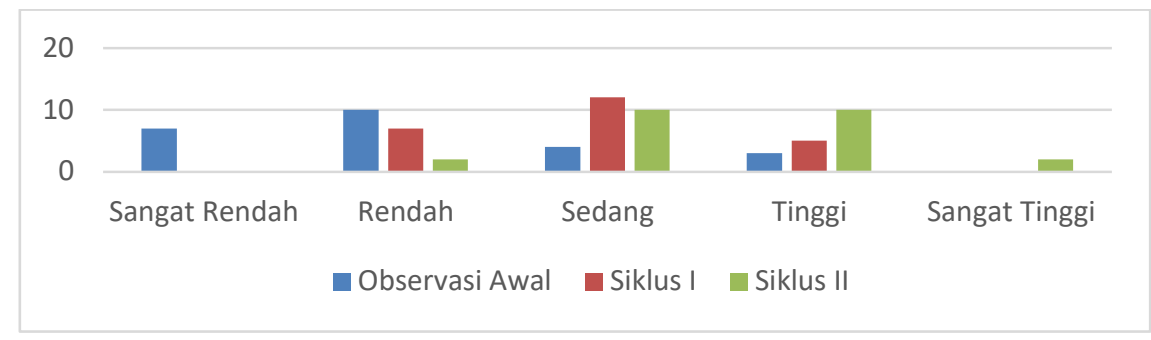

\section{Gambar 2. Diagram Perbandingan Kategori Tingkat Kemampuan Matematika Anak Pada Observasi Awal, Siklus 1 dan Siklus II}

\section{Pembahasan}

Penerapan model pembelajaran kooperatif tipe Jigsaw II mampu meningkatkan kemampuan matematika anak usia dini. Hal ini dapat dilihat dari perkembangan kemampuan anak dari saat observasi awal hingga akhir siklus II. Pada gambar 3 berikut, dapat diamati grafik perbandingan kemampuan matematika anak usia dini dari observasi awal hingga siklus II.

Berikut dapat dilihat perbandingan dan peningkatan kemampuan matematika masing-masing anak pada observasi awal, siklus I dan siklus II melalui Gambar 3.

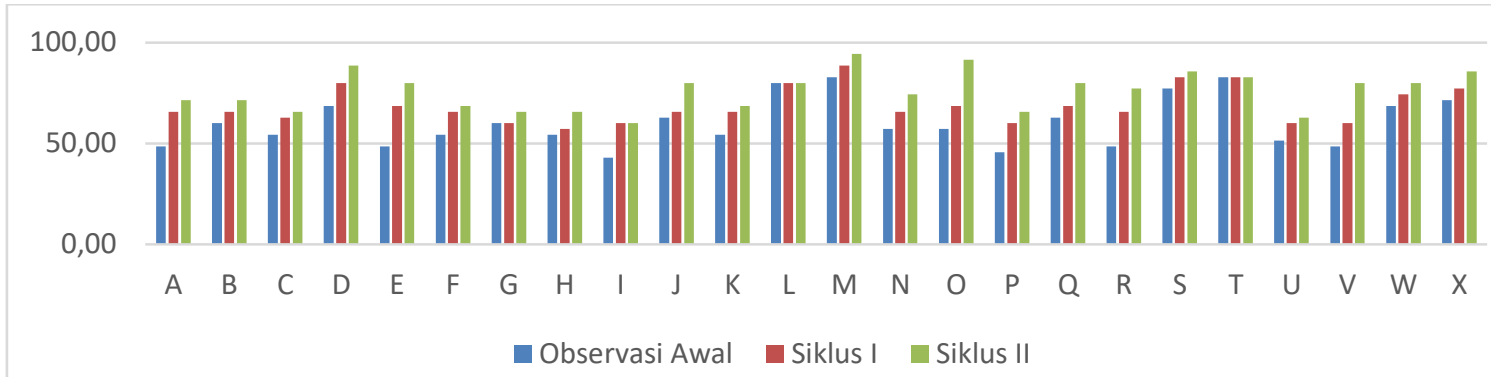

Gambar 3. Diagram Perbandingan Persentase Kemampuan Matematika Anak Pada Observasi Awal, Siklus 1 dan Siklus II

Ditinjau dari rata-rata nilai indikator pada instrumen penelitian dari 7 indikator ditemui 3 indikator yang mengalami peningkatan kemampuan matematika anak yang cukup besar pada siklus II dibandingkan dengan siklus I, indikator itu adalah Mengenal perbedaan berdasarkan ukuran: "lebih dari"; "kurang dari"; dan "paling/ter", Mengklasifikasikan benda berdasarkan warna, bentuk, dan ukuran (3 variasi), Mengenal pola $A B C D-A B C D$, Perbandingan rata-rata nilai tiap indikator dapat dijelaskan seperti pada gambar berikut. 


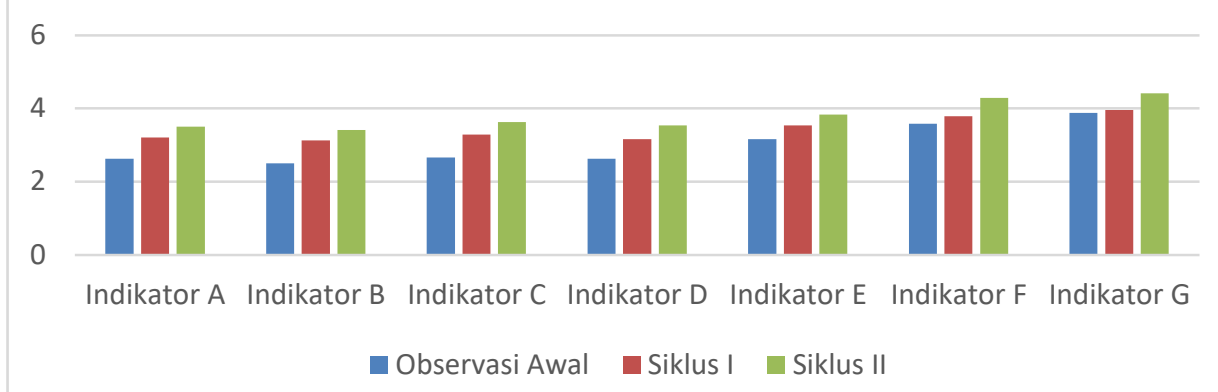

Gambar 4. Diagram Perbandingan Nilai Rata-Rata Tiap Indikator Kemampuan Matematika Pada Observasi Awal, Siklus 1 dan Siklus II

Kemampuan matematika anak meningkat pada siklus II merupakan keberhasilan dalam meminimalisir kendala yang ada, dan mengoptimalkan faktor-faktor yang mendukung, secara keseluruhan berdasarkan hasil pemantauan dan data observasi menunjukkan adanya peningkatan kemampuan matematika anak yang signifikan yaitu 91,67\% anak telah mencapai kriteria ketuntasan dengan kategori sedang dan tinggi dan sangat tinggi. Hal ini berarti bahwa penerapan model pembelajaran kooperatif tipe jigsaw II mampu meningkatkan kemampuan matematika anak.

Berikut disajikan perbandingan ketuntasan anak dalam kemampuan matematika pada observasi awal, siklus I dan siklus II.

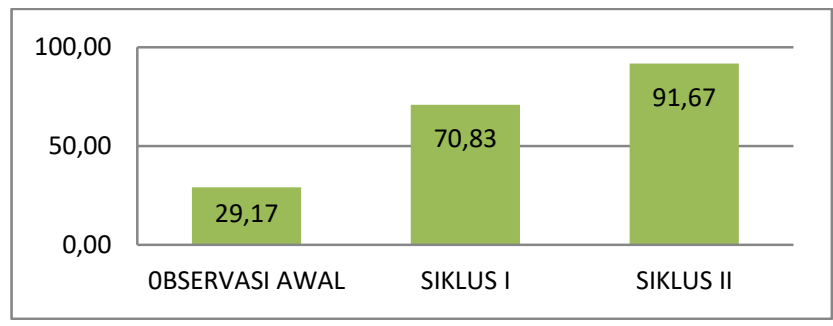

\section{Gambar 5. Diagram Perbandingan Ketuntasan Kemampuan Matematika Anak Pada Observasi Awal, Siklus 1 dan Siklus II}

Hasil penelitian membuktikan bahwa anak usia dini dapat belajar dan bekerjasama dalam kelompok dengan mengikuti diskusi dan bermain dalam permainan matematika dengan pimpinan teman sebaya sebagai tutor. Melalui pembelajaran kooperatif anak belajar membangun tanggung jawab diri sendiri dan anggota kelompoknya melalui suatu kepercayaan atas kemampuan dan bakat mereka, dan saling memberi penghargaan (Mashudi, 2016). Anak mampu menunjukkan sikap toleransi dan mandiri dalam membangun pengalaman dan pengetahuan tentang konsep matematika, sebagaimana hasil penelitian (Handayani, 2017) dan (Şengül and Katranci, 2014). Hal ini senada juga dengan hasil penelitian yang dilakukan oleh (Akçay, 2016) yang menyatakan bahwa metode jigsaw efektif diterapkan pada anak usia dini dalam mempelajari organ indera dan fungsinya, sedangkan penelitian Leasa (Leasa et al., 2019) yang berjudul "Jigsaw in teaching circulatory system: a learning activity on elementary science classroom" bahwa model pembelajaran kooperatif tipe jigsaw juga efektif diterapkan untuk pembelajaran sains pada anak Sekolah Dasar. Hal ini menyatakan bahwa kemampuan kognitif anak mampu dikembangkan melalui model pembelajaran kooperatif tipe jigsaw pada pembelajaran matematika dan sains. Selain meningkatkan kemampuan kognitif, model pembelajaran kooperatif tipe jigsaw juga efektif dalam meningkatkan kemampuan lainnya seperti keterampilan sosial (Wasito, 2017), kecerdasan intrapersonal (Fadillah, 2018) dan mempelajari PPKn (Elyawati, 2018), sehingga penerapan dan pengembangan model pembelajaran ini dapat dilanjutkan dalam penelitian mendatang. 
Peningkatan kemampuan matematika anak pada akhir penelitian menunjukkan bahwa implementasi model pembelajaran kooperatif tipe jigsaw II berbantuan konkret menjadi metode yang efektif dan kreatif hal ini sejalan hasil penelitian yang telah dilakukan oleh Rohmah dan Waluyo (Rohmah, 2014), yang berjudul "Arithmetic Dice Media as Counting Concept Introduction Media in Early Childhood Setting", Rusiman, Mohd Saifullah (2017) yang berjudul "The Use of Concrete Material in Teaching and Learning Mathematics" dan (Fauziddin, 2015) hasil penelitian menunjukkan penggunaan media benda konkret mampu meningkatkan kemampuan menghitung pada anak usia dini. Hal ini menegaskan bahwa anak usia dini dengan tingkat perkembangan kognitif pada fase praoperasional konkrit belum mampu berpikir secara abstrak, sehingga penggunaan media dengan benda konkret akan menolong anak untuk mempelajari konsep matematika lebih mudah dan efektif.

\section{SIMPULAN}

Melalui Model pembelajaran kooperatif tipe jigsaw II berbantuan benda kongkret, anak mempelajari matematika dengan cara menyenangkan dan bermakna, anak dapat mengkonstruksi pengetahuan tentang berbagai konsep melalui belajar dalam kelompok dengan benda konkret. Persentase ketuntasan kemampuan kogitif anak pada observasi awal sebesar $29,16 \%$. Kemampuan matematika anak mengalami peningkatan pada siklus I dan II. Sehingga dapat disimpulkan bahwa penerapan model pembelajaran kooperatif tipe jigsaw II berbantuan benda konkret dapat meningkatkan kemampuan matematika anak usia dini.

\section{UCAPAN TERIMA KASIH}

Terima kasih penulis ucapkan kepada semua pihak yang telah membantu dalam perencanaan dan pelaksanaan penelitian ini sehingga penulis dapat menyelesaikannya dengan baik dan lancar. Ucapan terima kasih ini khususnya ditujukan kepada Universitas Dhyana Pura, selaku pemberi dana hibah penelitian internal, Dr. I Gusti Bagus Rai Utama. SE., MA., M.MA, selaku Rektor Universitas Dhyana Pura, yang telah memberikan rekomendasi-rekomendasi guna kelancaran penyusunan penelitian, Dr. Jaya Pramono, S,Pd., M.Par, selaku Dekan Fakultas Ekonomika dan Humaniora Universitas Dhyana Pura, yang telah banyak memberikan arahan dalam pelaksanaan penelitian ini, Putu Chris Susanto, BA., MBA., M.Ed, selaku Ketua Lembaga Penelitian dan Pengabdian Masyarakat Universitas Dhyana Pura, yang telah banyak memberikan arahan dalam pelaksanaan penelitian ini, I Gusti Rai Citra , S.Pd, selaku kepala PAUD Tunas Mekar II Dalung yang telah memberikan ijin penulis untuk melaksanakan penelitian pada lembaga yang dipimpin, serta rekan guru PAUD Tunas Mekar II Dalung dan Reviewer dan editor Jurnal Obsesi yang memberi kesempatan artikel ini untuk diterbitkan

\section{DAFTAR PUSTAKA}

Agung, A. . G. (2014) Metode Penelitian Pendidikan. Malang: Aditya Media Publishing.

Akçay, N. O. (2016) 'Implementation of Cooperative Learning Model in Preschool', Journal of Education and Learning, 5(3), p. 83. doi: 10.5539/jel.v5n3p83.

Camposa, Helena, EurídiceTeixeira, P. C. (2015) 'Mathematics and Children's Literature Linked by E-Books', TOJET: The Turkish Online Journal of Educational Technology, 14.

Elyawati, E. (2018) 'Penerapan Model Pembelajaran Kooperatif Tife Jigsaw Untuk Meningkatkan Hasil Belajar Pkn Siswa Kelas V Sd Negeri Cikijing III Kecamatan Cikijing Kabupaten Majalengka', Jurnal Cakrawala Pendas, 4(1). doi: 10.31949/jcp.v4i1.714.

Fadillah, S. (2018) ‘Pengaruh Strategi Pembelajaran Kooperatif (Cooperatif Learning) dan Kecerdasan Intrapersonal terhadap Perilaku Prososial Anak Usia 5-6 Tahun di Kelurahan Umban Sari Pekanbaru', PAUD Lectura: Jurnal Pendidikan Anak Usia Dini, 2(01), pp. 91-102. doi: 10.31849/paudlectura.v2i01.2008. 
Fauziddin, M. (2015) 'Peningkatan Kemampuan Klasifikasi Melalui Media Benda Konkret pada Anak Kelompok A1 di TK Cahaya Kembar Bangkinang Kampar', Jurnal Obsesi: Jurnal Pendidikan Anak Usia Dini, 2(1). doi: 10.31004/obsesi.v1i2.65.

Hamdani (2011) Strategi Belajar Mengajar. Bandung: Pustaka Setia.

Handayani, H. (2017) ‘Upaya Meningkatkan Kemampuan Pemecahan Masalah Matematis dan Aktivitas Siswa Melalui Pembelajaran Kooperatif Learning Tipe Jigsaw di Kelas II Sekolah Dasar', Golden Age: Jurnal Pendidikan Anak Usia Dini, 1(1). doi: 10.29313/ga.v1i1.2687.

Ibrahim, R., S. N. (2003) Perencanaan Pengajaran. Jakarta: PT. Rinika Cipta.

Isjoni (2014) Cooperative Learning. Bandung: Alfabeta.

Jennah, R. (2009) Media Pembelajaran. Banjarmasin: Antasari Press.

Kartono, K. (2007) Psikologi Anak (Psikologi Perkembangan). Bandung: Cv. Mandar Maju.

Kemendikbud (2014) Permendikbud No 137, 2014. Standar Nasional Pendidikan Anak Usia Dini. Indonesia.

Kunandar (2010) 'Langkah mudah penelitian tindakan kelas sebagai pengembangan profesi guru'. Jakarta: PT Raja Grafindo Persada, pp. 55-76.

Leasa, M. et al. (2019) 'Jigsaw in teaching circulatory system: a learning activity on elementary science classroom', Biosfer, 12(2), pp. 122-134. doi: 10.21009/ biosferjpb.v12n2.122-134.

Li Ling Hu, and S. S. T. (2016) 'Applying an e-PBL Platform to Develop a Storytelling-Based Arithmetic Card Game', in Matec: Web of Conferences. doi: 10.1051/matecconf/2016/4401013.

Lipton, J. S. and Spelke, E. S. (2003) 'Origins of Number Sense: Large-number discrimination in Human Infants', Psychological Science, 14(5), pp. 396-401. doi: 10.1111/14679280.01453.

Majid, A. (2013) Strategi Pembelajaran. Bandung: PT Remaja Rosdakarya.

Mashudi, M. (2016) 'Strategi Pembelajaran Kooperatif Tipe Jigsaw Versus Pembelajaran Langsung', Universum, 10(2), pp. 149-162. doi: 10.30762/universum.v10i2.269.

Mayesky, M. (2002) Creative Activity for Young Children. Columbia: Delmar.

Mertler, C. A. (2011) Action Research. Yogyakarta: Pustaka Pelajar.

Papalia, D. E. D. (2008) Human Development (Psikologi Perkembangan) Bagian I s/d IV. Sembilan. Jakarta: Kencana Prenada Media Group.

Rohmah, N. dan E. W. (2014) 'Arithmetic Dice Media as Counting Concept Introduction Media in Early Childhood Setting', Indonesian Journal of Early Childhood Education Studies, 3(2), pp. 127-133.

Runtukahu, J. T. and S. K. (2014) Pembelajaran Matematika Dasar Bagi Anak Berkesulitan Belajar. Yogyakarta: Ar-Ruzz Media.

Rusiman, Mohd Saifullah, D. (2017) 'Arithmetic Dice Media as Counting Concept Introduction Media in Early Childhood Setting', Journal of Engineering and Applied Sciences, 12(8), p. 2170=2174.

Şengül, S. and Katranci, Y. (2014) 'Effects of Jigsaw Technique on Seventh Grade Primary School Students' Attitude towards Mathematics', Procedia - Social and Behavioral Sciences, 116, pp. 339-344. doi: 10.1016/j.sbspro.2014.01.218.

Sumyadewi, Ni Luh, D. (2014) 'Penerapan Model Pembelajaran Cooperative Learning Tipe Jigsaw Berbantuan Media Kartu Angka Bergambar Untuk Meningkatkan Perkembangan Kognitif Anak TK Widhya Brata Mengwi', e-Journal PG-PAUD Universitas Pendidikan Ganesha Jurusan Pendidikan Guru Pendidikan Anak Usia Dini., 2(1).

Wasito, D. R. H. I. (2017) 'Efektivitas Pembelajaran Kooperatif (Cooperative Learning) Untuk Meningkatkan Keterampilan Sosial Pada Siswa Taman Kanak-Kanak', Jurnal Psikologi Ulayat, 4(2), pp. 160-174. doi: 10.24854/jpu22017-101. 